\title{
Structure, composition and tree diversity in a temperate forest under management
}

\section{Estructura, composición y diversidad arbórea en un bosque templado bajo manejo}

\author{
MORA-SANTACRUZ, Antonio $\dagger$, ROMÁN-MIRANDA, María Leonor*, NUNGARAY- \\ VILLALOBOS, Omar and GONZÁLEZ-CUEVA, Gerardo Alberto
}

Departamento de Producción Forestal, Centro Universitario de Ciencias Biológicas y Agropecuarias. Universidad de Guadalajara

ID $1^{\text {st }}$ Author: Antonio, Mora-Santacruz / ORC ID: 0000-0002-6169-2077, Researcher ID Thomson: T-4708-2018, CVU CONACYT ID: 96712

ID $1^{\text {st }}$ Coauthor: María Leonor, Román-Miranda / ORC ID: 0000-0002-9420-2150M, Researcher ID Thomson: T-46082018, CVU CONACYT ID: 264122

ID $2^{\text {nd }}$ Coauthor: Omar, Nungaray-Villalobos

ID $3^{\text {rd }}$ Coauthor: Gerardo Alberto, González-Cueva / ORC ID: 0000-0003-3231-674X, Researcher ID Thomson: T-42912018, CVU CONACYT ID: 16912

DOI: $10.35429 / J E S N .2019 .15 .5 .29 .35$

Received April 26, 2019; Accepted June 30, 2019

\begin{abstract}
In order to study both diversity indices and structure of forests, which are an essential tool for decision-making in forest management, which show natural successional processes and effects for its management. So the objetive of this study was to evaluate structure and diversity of arboral species in a temperate forest of southern Jalisco state. Five permanent forestry research sites 50 x 50 $\left(2.500 \mathrm{~m}^{2}\right)$ were established, and a census of all tree species was carried out, with normal diameter greater than $7.5 \mathrm{~cm}$. Each individual was measured: height and normal diameter, placing an aluminum plate for identification. We obtained the importance value index (IVI), indices of diversity, richness, and dasometric parameters. There were 17 species, 9 genera and 9 botanical families; the Fagaceae was dominant. Pinus douglasiana presented the highest IVI (57.93\%); The Shannon index had a value of 2.0; the index of Margalef was 2.4; the forest has a density of 688 trees ha-1, being the most abundant Styrax ramirezii; Pinus herrerae obtained the highest values in basal area and volume with $30.77 \mathrm{~m}^{2}$ ha- 1 and $357,325 \mathrm{~m}^{3}$ ha- 1 respectively. The values of diversity are influenced by elements of the cloud forest
\end{abstract}

Dasometric parameters, Diversity índices and Permanent plots

\begin{abstract}
Resumen
El conocimiento de los índices de diversidad y estructura de los bosques, son una herramienta esencial para la toma de decisiones en el manejo forestal, que muestran procesos sucesionales naturales y efectos por su manejo. Por lo que el objetivo del estudio fue evaluar estructura y diversidad de especies arbóreas en un bosque templado del sur de Jalisco. Se establecieron cinco sitios permanentes de muestreo de $50 \times 50 \mathrm{~m}\left(2,500 \mathrm{~m}^{2}\right)$, se realizó un censo de especies arbóreas con diámetro normal mayor a $7.5 \mathrm{~cm}$, de cada individuo se midió altura total y diámetro normal, colocando una placa de aluminio para su identificación. Se obtuvo el índice de valor de importancia (IVI), índices de diversidad, riqueza y parámetros dasométricos. Se registraron 17 especies, 9 géneros y 9 familias botánicas; la Fagaceae fue dominante. Pinus douglasiana presentó el mayor IVI (57.93\%); el índice de Shannon tuvo un valor de 2.0; el índice de Margalef fue de 2.4; el bosque presenta una densidad de 688 árboles ha ${ }^{-1}$, siendo Styrax ramirezii la más abundante; Pinus herrerae obtuvo los mayores valores en área basal y volumen con $30.77 \mathrm{~m}^{2} \mathrm{ha}^{-1} \mathrm{y}$ $357.325 \mathrm{~m}^{3} \mathrm{ha}^{-1}$ respectivamente. Los valores de diversidad se ven influenciados por elementos del bosque mesófilo.
\end{abstract}

Indices de diversidad, Parámetros dasométricos y Sitios permanente

Citation: MORA-SANTACRUZ, Antonio, ROMÁN-MIRANDA, María Leonor, NUNGARAY-VILLALOBOS, Omar and GONZÁLEZ-CUEVA, Gerardo Alberto. Structure, composition and tree diversity in a temperate forest under management. Journal of Environmental Sciences and Natural Resources. 2019, 5-15: 29-35

\footnotetext{
* Correspondence to Author (email: maryleo7rom@gmail.com)

$\dagger$ Researcher contributing first author.
} 


\section{Introduction}

Mexico is part of the mega diverse countries, with the largest area of primary forests in the world, the nation is located in the fourth place in species richness (SEMARNAT, 2011). It has a wooded area greater than 64.8 million hectares, of which $52 \%$ correspond to temperate forests (Challenger, 1998; CONAFOR, 2012; FAO, 2006).

Previously it was believed that forests were an inexhaustible source of resources, however, this concept has been restructuring as the loss of forest masses increases, which causes the decrease of biodiversity worldwide, which results in the temperature increase (Uribe, 2015). Forest management is a tool that allows to maintain forests and obtain goods and services that they offer.

The importance of knowing the biodiversity of ecosystems, through the indexes of diversity is fundamental in forest management, since silvicultural management practices modify or deteriorate the habitat. Changes in the structure and diversity of the forest can be generated by selective use (Corral et al., 2005).

The forests of the southeastern region of Jalisco are the most important timber in the state, these forests have been used for more than 80 years, applying various management regimes to obtain regular and irregular structures, dominating the latter with short selection. Considering the importance of forest management in this region, especially the Barranca del Calabozo ejido, five permanent forestry research sites were established, in order to assess the dynamics of the forest that allows decisions to be made within the framework of sustainable management. In this context, the objective of this research was: to evaluate the structure, composition and tree diversity in stands under management of temperate forests of southeastern Jalisco.

\section{Methodology}

The study was carried out in the El Malacate fraction of the Barranca del Calabozo ejido, in the municipality of Pihuamo, Jalisco. Geographically it is located between the extreme coordinates of $19{ }^{\circ} 20$ '18.9 "north latitude and $103^{\circ} 15^{\prime} 24.3^{\prime \prime}$ west longitude.
The climate according to the Köppen classification modified by García (1987), is of type C (w2) that corresponds to a temperate, sub humid climate with rains in summer; With an average annual temperature between $18^{\circ} \mathrm{C}$ and a rainfall of $1200 \mathrm{~mm}$ per year (INIFAP, 2012), the soils are of the chromic Luvisol type, with great moisture retention capacity, thick thickness, with a good amount of cation exchange. ( FAO UNESCO, 1990); the vegetation is formed by pine-oak forests with fractions of mountain mesophilic forest, the altitude is $2300 \mathrm{~m}$.

The dasometric information was obtained from five permanent 50 x $50 \mathrm{~m}(2,500$ m2) forest research sites, based on the methodology recommended by Corral et al. (2009). A woodland census was performed, registering trees with normal diameter equal to or greater than $7.5 \mathrm{~cm}$; total height, in addition to all the trees an aluminum plate was placed at the height of $1.30 \mathrm{~m}$, with consecutive number for identification.

To determine the tree composition, the common name and scientific name of each individual was recorded. To estimate species richness, the Margalef index (DMg) was used and for Shannon-Wiener index (H'), using the formulas (Magurran, 2004).

$D_{M g}=\frac{S-1}{\ln N}$

Where:

$S=$ number of species present

$\ln =$ natural logarithm

$N=$ total number of individuals summing all species

Shannon-Wiener index was estimated from the following expression:

$H^{\prime}=\sum p i \ln p i$

$p i=\frac{n i}{N}$

Where:

$p i=$ Proportion of individuals of the species $i$ with respect to the total number of individuals (ie the relative abundance of the species i)

$l n=$ Natural logarithm

$n i=$ Number of individuals of the species $i$.

$N=$ Total number of individuals. 
To estimate the importance value index (IVI) proposed by Curtís and Mcintosh (1951), it is defined by the equation:

IVI $=$ Relative abundance + Relative dominance + Relative frequency

Where:

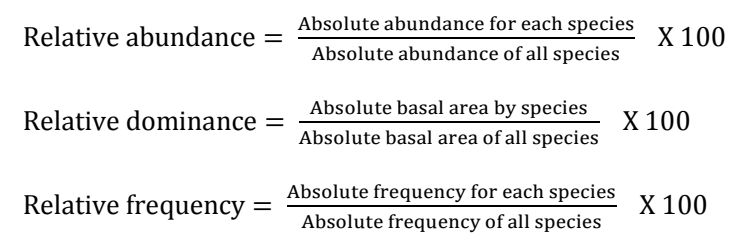

The dasometric parameters

Trees per hectare (density): number of trees registered at the sampling sites and inferred to the hectare. The basal area by species was determined with the following formula:

$G=\frac{\pi * D N^{2}}{4}$

Where:

$G=$ Basal area $\left(\mathrm{m}^{2}\right)$.

$\pi=$ (pi) The ratio between the circumference and the diameter of a circle.

$D N=$ Normal diameter at height $(1.30 \mathrm{~m})$

To estimate the total volume per tree, of the genus Pinus and Quercus, the models generated for the Forest Management Unit (UMAFOR) 1404 “Cd Guzmán” were used, in the CONACYT-CONAFOR agreement (2013). For the species considered other leafy or other broadleaved species, the models used in the Comprehensive Management Program of the Atenquique Region (Table 1) were used.

\begin{tabular}{|c|c|}
\hline Species & Model \\
\hline Pinus douglasiana & vtacc $=0.0000378 * \mathrm{~d}^{1.91}$ \\
\hline $\begin{array}{l}\text { Pinus devoniana } \\
\text { Pina }\end{array}$ & vtacc $=0.0000478 * \mathrm{~d}^{2.1064443 *} \mathrm{~h}^{0.800508}+0.0001054 * \mathrm{~d}^{2}$ \\
\hline Pinus herrerae & vtacc $=0.0000654 * \mathrm{~d}^{1.99208441} * \mathrm{~h}^{0.8413872}+0.0000714 * \mathrm{~d}^{2}$ \\
\hline Pinus oocarpa & vtacc $=0.0000538 * \mathrm{~d}^{2.0733857} * \mathrm{~h}^{0.79985558}+0.0000895 * \mathrm{~d}^{2}$ \\
\hline Quercus candicans & vtacc $=0.0000765 * \mathrm{~d}^{1.8181666} * \mathrm{~h}^{0.9334637}+0.0002233 * \mathrm{~d}^{2}$ \\
\hline Quercus crassifolia & vtacc $=0.0000337 * \mathrm{~d}^{1.9711755} * \mathrm{~h}^{1.0224766}+0.0002726 * \mathrm{~d}^{2}$ \\
\hline Quercus castanea & vtacc $=0.00006682 * \mathrm{~d}^{1.868929} * \mathrm{~h}^{0.91262}+0.0003244 * \mathrm{~d}^{2}$ \\
\hline Quercus rugosa & vtacc $=0.0000381 * \mathrm{~d}^{1.9415088} * \mathrm{~h}^{1.0189592}+0.0002529 * \mathrm{~d}^{2}$ \\
\hline Quercus obtusata & vtacc $=0.0000218 * \mathrm{~d}^{1.9324875} * \mathrm{~h}^{1.2333404}+0.0002094 * \mathrm{~d}^{2}$ \\
\hline Quercus laurina & 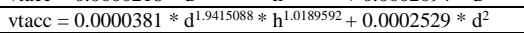 \\
\hline Styrax ramirezii & $\operatorname{Ln}(\operatorname{vacc})=-11.162+2.417212 * \operatorname{Ln}(\mathrm{d})+0.835947 * \operatorname{Ln}(\mathrm{h})$ \\
\hline Arbutus xalapensis & $\operatorname{Ln}(\operatorname{vacc})=-11.162+2.417212 * \operatorname{Ln}(\mathrm{d})+0.835947 * \operatorname{Ln}(\mathrm{h})$ \\
\hline Clethra lanata & $\operatorname{Ln}(\operatorname{vtacc})=-11.162+2.417212 * \operatorname{Ln}(\mathrm{d})+0.835947 * \operatorname{Ln}(\mathrm{h})$ \\
\hline Podocarpus matudae & $\operatorname{Ln}(\operatorname{vtacc})=-11.162+2.417212 * \operatorname{Ln}(\mathrm{d})+0.835947 * \operatorname{Ln}(\mathrm{h})$ \\
\hline Ternstroemia sp. & $\operatorname{Ln}(\operatorname{vtacc})=-11.162+2.417212 * \operatorname{Ln}(\mathrm{d})+0.835947 * \operatorname{Ln}(\mathrm{h})$ \\
\hline Crataegus mexicana & $\operatorname{Ln}(\operatorname{vacc})=-11.162+2.417212 * \operatorname{Ln}(\mathrm{d})+0.835947 * \operatorname{Ln}(\mathrm{h})$ \\
\hline Carpinus caroliniana & $\operatorname{Ln}(\operatorname{vtacc})=-11.162+2.417212 * \operatorname{Ln}(d)+0.835947 * \operatorname{Ln}(\mathrm{h})$ \\
\hline
\end{tabular}

Tabla1 Mathematical models to estimate volumes per tree, where vtacc $=$ total volume tree with bark, $d=$ normal diameter and $\mathrm{h}=$ total height

\section{Results and Discussion}

Floristic composition

The floristic composition of the tree stratum is represented by pine-oak forests and a portion of mesophilic mountain forest. 17 species, 9 genera, 9 families and five orders were registered. The best represented families were: Fagaceae with six species, followed by the Pinaceae family with four species (Table 2).

\begin{tabular}{|c|c|c|}
\hline Species & Family & Order \\
\hline Arbutus xalapensis Kunth & Ericaceae & Ericales \\
\hline Carpinus caroliniana Walter & Betulaceae & Fagales \\
\hline Clethra lanata M. Martens \& Galeotti & Clethraceae & Fagales \\
\hline Crataegus mexicana Loudon & Rosaceae & Rosales \\
\hline Quercus candicans Née & Fagaceae & Fagales \\
\hline Q. castanea Née & Fagaceae & Fagales \\
\hline Q. crassifolia Bonpl. & Fagaceae & Fagales \\
\hline Q. obtusata Bonpl. & Fagaceae & Fagales \\
\hline Q. laurina Humb. Et Bonpl & Fagaceae & Fagales \\
\hline Q. rugosa Née & Fagaceae & Fagales \\
\hline Pinus devoniana Lindl. & Pinaceae & Pinales \\
\hline Pinus douglasiana Martínez & Pinaceae & Pinales \\
\hline Pinus herrerae Martínez & Pinaceae & Pinales \\
\hline Pinus oocarpa Schiede ex Schtdl. & Pinaceae & Pinales \\
\hline Podocarpus matudae Lundell & Podocarpaceae & Ericales \\
\hline Styrax ramirezii Greenm. & Styracaceae & Ericales \\
\hline Ternstroemia $s p$. & Penthaphylacaceae & Ericales \\
\hline
\end{tabular}

Table 2 Tree species present in the study area

Unlike what was reported by GracianoÁvila et al. (2017), Those who studied an area of $2.50 \mathrm{ha}$, in a pine and pine-oak forest in the state of Durango, where they pointed to the Pinaceae family with a greater number of species (five), it should also be noted that although in our case it was a smaller sampled area (1.25 ha), a greater diversity of species was obtained with 17 against 13 , represented in nine families against five, reported in the study cited and was even greater than that indicated by López-Hernández et al . (2017) in Puebla with only 11 species in five genera.

Figure 1 shows the distribution of trees by species; the total density was 860 individuals, distributed in 17 species; Styrax ramirezii (200 trees), Pinus douglasiana (186 trees), P. herrerae (180 trees) and Quercus candicans (124 trees) were the ones with the highest density, the rest $(170$ trees $)$ complements the total. Carpinus caroliniana (1 tree) and Podocarpus matudae (15 trees), are listed within NOM-059-SEMARNAT-2010, threatened (A) and with special protection $(\mathrm{Pr})$, respectively. 


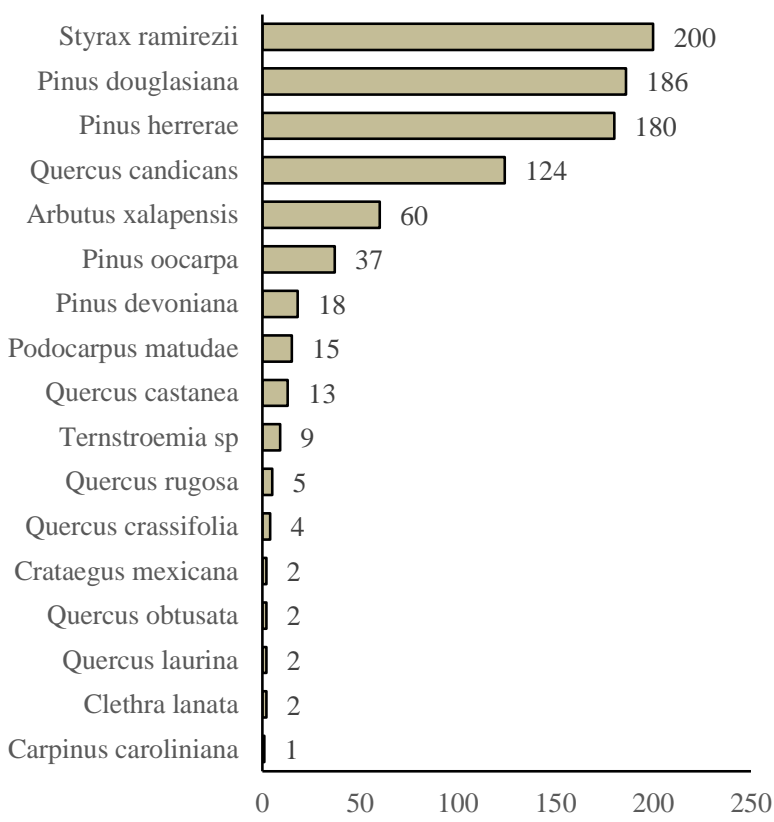

Graphic 1 Número de árboles por especie

\section{Diversity}

The species richness index of Margalef (DMg) was 2.4, higher than that reported by Návar and González (2009) of 1.04, in Durango forests and by Hernández et al. (2013) in temperate forests of Chihuahua of 0.9. The ShannonWiener ( $\mathrm{H}^{\prime}$ ') diversity index was 2.0; This diversity value is greater than that reported by García et al (2012) in forests in the Sierra Madre Oriental of the state of Nuevo León, and by Hernández et al (2013), in temperate forests of Chihuahua with 0.34 .

\section{Importance Value Index}

\section{Abundance}

The most abundant species were: Styrax ramirezii with 200 trees, which represented $23.26 \%$ of the total; followed by Pinus douglasiana (186 trees), which represent $21.63 \%$ and P. herrerae (180 trees) with $20.93 \%$ of the total.

\section{Dominance}

The total basal area was $30.77 \mathrm{~m}^{2}$, where the most dominant species were: Pinus herrerae $\left(11.75 \mathrm{~m}^{2}\right)$ representing $30.55 \%$ of the total species, followed by P. douglasiana (9.03) with $23.48 \%$. The two species make up $43.03 \%$ of the total of 17 species found.

\section{Frequency}

The most frequent species are Pinus douglasiana and Arbutus xalapensis (they occur in all sampling sites) with a frequency of $12.82 \%$, followed by Styrax ramirezii and Pinus devoniana with $10.26 \%$, the other species have lower values. The species with the highest importance value index (IVI) was P. douglasiana (57.93\%), P. herrerae (56.61\%) and Styrax ramirezii $(42.88 \%)$, were the most outstanding spices having the highest values, the species more rare, with less value was Carpinus caroliniana with $0.90 \%$. (Graphic 2, Table 3). Graciano-Avila et.al. (2013) report that P. cooperi (79.05\%) and P. durangensis (70.89\%) had the highest IVI values, these species were the most important in forests of the $\mathrm{La}$ Victoria de Durango ejido.

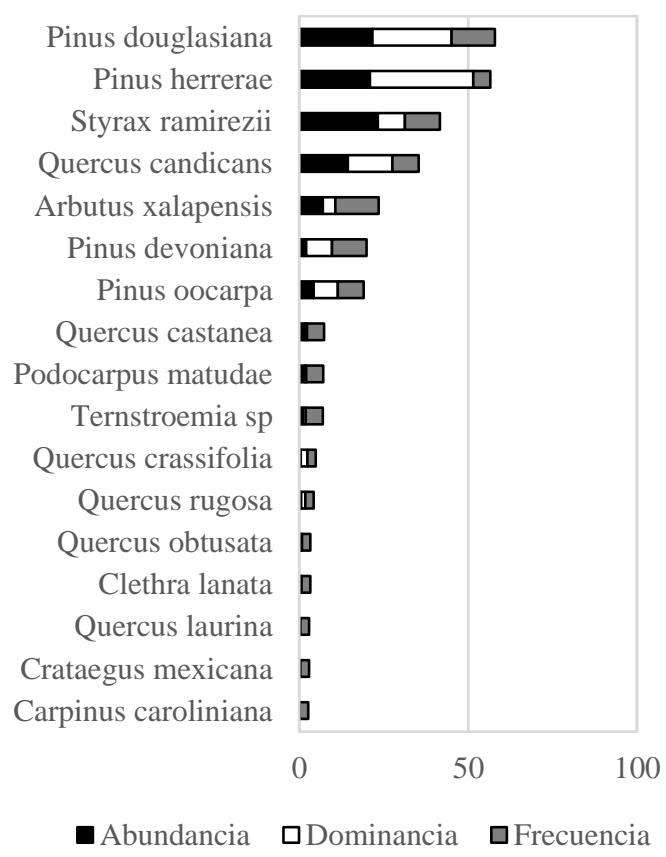

Graphic 2 Importance Value Index (IVI)

\begin{tabular}{|c|c|c|c|c|c|c|c|}
\hline \multirow[b]{2}{*}{ Species } & \multicolumn{2}{|c|}{ Abundance } & \multicolumn{2}{|c|}{ Dominance } & \multicolumn{2}{|c|}{ Frequency } & \multirow[b]{2}{*}{ IVI } \\
\hline & Abs. & $\begin{array}{l}\text { Rel } \\
(\%)\end{array}$ & Abs. & $\begin{array}{l}\text { Rel } \\
(\%)\end{array}$ & Abs. & $\begin{array}{l}\text { Rel } \\
(\%)\end{array}$ & \\
\hline Pinus douglasiana & 186 & 21.63 & 9.03 & 23.48 & 5 & 12.82 & 57.93 \\
\hline Pinus herrerae & 180 & 20.93 & 11.75 & 30.55 & 2 & 5.13 & 56.61 \\
\hline Styrax ramirezii & 200 & 23.26 & 3.11 & 8.09 & 4 & 10.26 & 42.88 \\
\hline Quercus candicans & 124 & 14.42 & 5.08 & 13.21 & 3 & 7.69 & 39.17 \\
\hline Arbutus xalapensis & 60 & 6.98 & 1.41 & 3.68 & 5 & 12.82 & 21.23 \\
\hline Pinus devoniana & 18 & 2.09 & 2.91 & 7.57 & 4 & 10.26 & 18.31 \\
\hline Pinus oocarpa & 37 & 4.3 & 2.75 & 7.15 & 3 & 7.69 & 18.18 \\
\hline Quercus castanea & 13 & 1.51 & 0.29 & 0.76 & 2 & 5.13 & 7.08 \\
\hline Podocarpus matudae & 15 & 1.74 & 0.11 & 0.28 & 2 & 5.13 & 1.53 \\
\hline Ternstroemia $s p$ & 9 & 1.05 & 0.34 & 0.87 & 2 & 5.13 & 1.50 \\
\hline Quercus crassifolia & 4 & 0.47 & 0.74 & 1.91 & 2 & 5.13 & 7.08 \\
\hline Quercus rugosa & 5 & 0.58 & 0.46 & 1.19 & 1 & 2.56 & 1.45 \\
\hline Quercus obtusata & 2 & 0.23 & 0.21 & 0.54 & 1 & 2.56 & 1.11 \\
\hline Clethra lanata & 2 & 0.23 & 0.19 & 0.48 & 1 & 2.56 & 1.95 \\
\hline Quercus laurina & 2 & 0.23 & 0.05 & 0.13 & 1 & 2.56 & 0.98 \\
\hline Crataegus mexicana & 2 & 0.23 & 0.03 & 0.08 & 1 & 2.56 & 0.96 \\
\hline Carpinus caroliniana & 1 & 0.12 & 0.01 & 0.03 & 1 & 2.56 & 0.90 \\
\hline Total & 860 & 100 & 38.47 & 100 & 39 & 100 & 300 \\
\hline
\end{tabular}

Table 3 Abundance, dominance, frequency and Importance Value Index of the species (sorted in descending order according to their IVI) 


\section{Dasometric Parameters}

\section{Individuals by diametric category}

Individuals by diametric category the horizontal structure shows an irregular, incoethane structure in the form of an inverted " $\mathrm{J}$ " (Liocourt curve). The largest number of individuals correspond to the smaller categories, between 10 and $15 \mathrm{~cm}$ in normal diameter, with few individuals larger than 70 $\mathrm{cm}$. The group of other leaflets as a whole has smaller diameters, not larger than $40 \mathrm{DN}$, while the group of the genus Pinus showed the largest diameters with records of 90 to $105 \mathrm{~cm} \mathrm{DN}$ (Graphic 3). Juarez et al. (2014) analyzed the silvicultural structure of a temperate forest in Tamaulipas, Mexico, reporting the largest number of trees in diametric categories between 10 and $20 \mathrm{~cm}$ of the Quercus and Pinus genera, similar to those obtained in the present study.

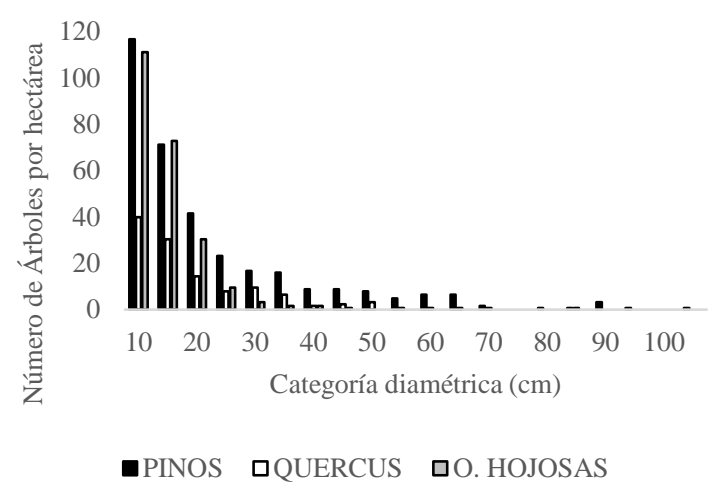

Graphic 3 Diameter distribution

\begin{tabular}{|l|r|r|r|r|r|}
\hline Species & Arb/ha & $\begin{array}{l}\text { AB/ha } \\
\left(\mathrm{m}^{2}\right)\end{array}$ & \multicolumn{2}{|l|}{$\begin{array}{l}\text { Vol/ha } \\
\left(\mathrm{m}^{3}\right)\end{array}$} & \multicolumn{2}{l}{$\begin{array}{l}\text { Altura } \\
\text { media } \\
(\mathrm{m})\end{array}$} & $\begin{array}{l}\text { DN } \\
\text { Medio } \\
(\mathrm{cm})\end{array}$ \\
\hline Pinus devoniana & 14.4 & 2.3284 & 32.311 & 21.44 & 41.25 \\
\hline Pinus douglasiana & 148.8 & 7.2266 & 81.342 & 15.47 & 20.58 \\
\hline Pinus herrerae & 144.0 & 9.4016 & 141.680 & 16.10 & 21.58 \\
\hline Pinus oocarpa & 29.6 & 2.1995 & 24.572 & 16.75 & 27.93 \\
\hline Quercus candicans & 99.2 & 4.0653 & 41.412 & 12.08 & 19.19 \\
\hline Quercus castanea & 10.4 & 0.2337 & 2.176 & 8.31 & 15.25 \\
\hline Quercus crassifolia & 3.2 & 0.5888 & 4.895 & 12.13 & 47.81 \\
\hline Quercus laurina & 1.6 & 0.0404 & 0.411 & 11.95 & 16.43 \\
\hline Quercus obtusata & 1.6 & 0.1669 & 1.463 & 14.40 & 35.90 \\
\hline Quercus rugosa & 4.0 & 0.3669 & 3.165 & 12.18 & 33.54 \\
\hline Arbutus xalapensis & 48.0 & 1.1310 & 6.756 & 9.98 & 15.93 \\
\hline Carpinus caroliniana & 0.8 & 0.0089 & 0.039 & 13.00 & 11.90 \\
\hline Clethra lanata & 1.6 & 0.1480 & 1.285 & 17.40 & 33.05 \\
\hline Crataegus mexicana & 1.6 & 0.0245 & 0.088 & 8.75 & 13.45 \\
\hline Podocarpus matudae & 12.0 & 0.0858 & 0.269 & 9.25 & 9.44 \\
\hline Styrax ramirezii & 160.0 & 2.4898 & 13.904 & 13.29 & 13.25 \\
\hline Ternstroemia sp & 7.2 & 0.2692 & 1.557 & 12.40 & 19.06 \\
\hline Total & 688.0 & 30.7754 & 357.325 & & \\
\hline
\end{tabular}

Table 4. Dasometric parameters

\section{Trees per hectare}

The density expressed in number of trees per hectare was 688; the species that presented the greatest amount were: Styrax ramirezii, Pinus douglasiana and P. herrerae with 160, 148.8 and $144 \mathrm{ha}^{-1}$ trees, the rest $\left(235.2 \mathrm{ha}^{-1}\right.$ trees $)$ are made up of the other 13 species. The density of 688 ha-1 trees can be considered high, compared to that obtained by Martínez, et al (2012). In permanent research sites "El Poleo" Madera, in Chihuahua, where they report values from 348,404 to $1,272 \mathrm{ha}^{-1}$ trees, the latter mostly corresponds to young trees.

\section{Basal area per hectare}

In the case of the total basal area per hectare, it was $30,775 \mathrm{~m}^{2}$; the highest values corresponded to the genus Pinus with 21,156 m2 ha-1, followed by the genus Quercus with 5,462 $\mathrm{m}^{2}$ ha- 1 and other leafy with $4,157 \mathrm{~m} 2$ ha- 1 . The values of the basal area are similar to those reported by Martínez, et al. (2012), where it reports values from 22.1 to $30.6 \mathrm{~m} 2 \mathrm{ha}^{-1}$.

\section{Volume per hectare}

For the determination of the volume, the absolute values of the five sampling sites were used and subsequently the inference was made for one hectare. The total volume per hectare grouping all trees was $357,325 \mathrm{~m}^{3}$ (total tree volume); the Pinus had the highest volumes with $279,905 \mathrm{~m} 3 \mathrm{ha}^{-1}$, followed by the genus Quercus with 53,522 $\mathrm{m}^{3} \mathrm{ha}^{-1}$ and the other leafy with 23,898 m3. ha-1 (Graphic 4)

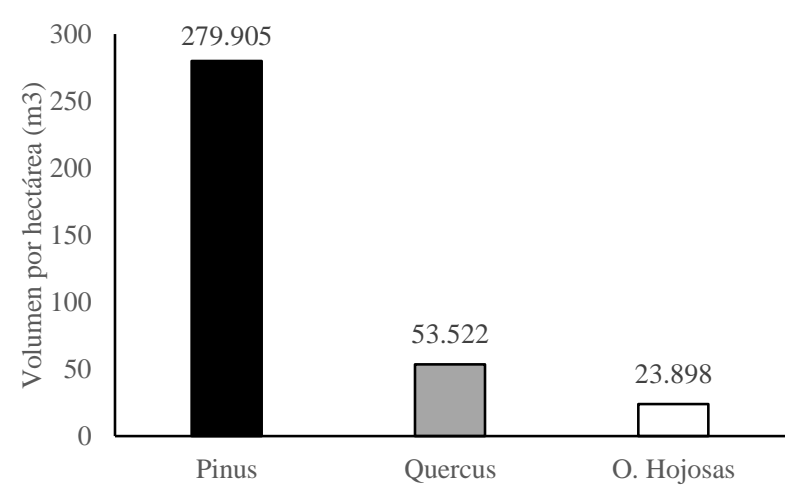

Graphic 4 Volume per hectare by gender and group of species

Martínez, et al. (2012), reported volumes from 88.6 to $261.7 \mathrm{~m} 3$. ha-1 and Reyes et al. (2016) in Durango forests, they indicated total real stocks, inferred to the hectare of up to $198,625 \mathrm{~m} 3$. 
In both cases the volumes are lower than those obtained in the present study, which indicates that the stands where the sampling sites were located have good site quality, that is, they are areas with good timber production.

\section{Conclusions}

The tree floristic composition is represented by 17 species, 9 genera, grouped into 9 families and 5 orders. The best represented botanical family was Fagaceae.

The specific wealth of the studied community was 17 species, with a Margalef index $\left(D_{m g}\right)$ of 2.4 ; in relation to the value of diversity, the Shannon-Wiener index (H') was 2.0. Apparently, the diversity values were influenced by elements of the mountain mesophilic forest.

The importance value index (IVI) indicates that P. douglasiana $(57.93 \%)$, P. herrerae $(56.61 \%)$ and Styrax ramirezii $(42.88 \%)$, were the most outstanding spices having the highest values.

The volume per hectare of all species was $357,325 \mathrm{~m}^{3} \mathrm{ha}^{-1}$; the highest volume corresponded to the genus Pinus $\left(279,905 \mathrm{~m}^{3}\right.$. $\left.\mathrm{ha}^{-1}\right)$, followed by the genus Quercus $(53,522$ $\mathrm{m} 3$. $\mathrm{ha}^{-1}$ ) and with the lowest volumes for the other leafy $\left(23,898 \mathrm{~m} 3 . \mathrm{ha}^{-1}\right)$. P. herrerae, was the species with the highest volume with $141,680 \mathrm{~m}^{3} \cdot \mathrm{ha}^{-1}$

The stands where the sampling sites were located presented a good site quality, that is, they are areas with good timber production.

\section{Acknowledgments}

To the University of Guadalajara and to the 2016 Academic Bodies Strengthening Program (IDCA 23528). To the ejido authorities, to the forestry consultancy "Asesores Forestales de Occidente" S. A., especially to the director Ing. Aldo Rivera and the Association of Foresters of the Sierra del Tigre, El Halo and the Volcanoes.

\section{References}

Challenger, A. 1998. Utilización y conservación de los ecosistemas terrestres de México, pasado, presente y futuro de México, CONABIO, Instituto de Biología, UNAM, Agrupación Sierra Madre, S.C.P., 847 p.

Clifford, H.T. y Stephenson, W. 1975. An introduction to numerical classification. Academic Press, London. 350 pp.

CONAFOR (Comisión Nacional Forestal). 2012. Inventario Nacional Forestal y de Suelos, informe del 2004-2009 (1a. ed). Zapopan, Jalisco, México: CONAFOR. 22 p.

CONAFOR-CONACYT. 2013. SiBiFor Biblioteca digital del sistema biométrico para la planeación del manejo forestal sustentable de los ecosistemas con potencial maderable en México.

http://fcfposgrado.ujed.mx/sibifor/inicio/buscar. php?a=volumen \%20total0arbol\#,

Corral-Rivas, J. J.; Aguirre, O.; Jiménez, J. y Corral, S. 2005. Un análisis del efecto del aprovechamiento forestal sobre la diversidad estructural en el Bosque Mesófilo de Montaña "El Cielo", Tamaulipas, México. Investigaciones Agrarias: Sistemas de Recursos Forestales, 14 (2), 217-228.

Corral-Rivas, J. J.; Vargas, L.B.; Wehekel, C.; Aguirre, C. O.; Álvarez, G. J. y Rojo, A.A. 2009. Guía para el Establecimiento de Sitios de Investigación Forestal y de Suelos en Bosques del Estado de Durango. Editorial UJED. Durango. 81p.

Curtis J.y Mcintosh R. 1951. An upland forest continuum in the pariré-forest border región of Wisconsin. Ecology 32: 476-496 p.

FAO. 2006. Tendencias y perspectivas del sector forestal en America Latina y el Caribe. Roma 60: 100 p.

FAO-UNESCO. 1990. Mapa mundial de suelos. Informes sobre recursos mundiales de suelos. Organización de las Naciones Unidas para la Agricultura y la Alimentación. Roma. 60: $142 \mathrm{p}$. 
García., E. 1987. Modificaciones al sistema de clasificación climática de Köppen. Instituto de Geografía, UNAM. México. 246 p.

González E. S.; González, E. M. y Cortez O. A. 1993. Vegetación de la reserva de la biosfera "La Michilia", Durango, México. Acta Botánica Mexicana, 22, 1-104.

Graciano, A.G.; Aguirre, C.O.A.; Alanis R.E. y Lujan S.J.E 2017. Composición, estructura y diversidad de especies arbóreas en un bosque templado del noroeste de México. Ecosistemas y Recursos Agropecuarios, 4(12), 535-542. doi: 10.19136/era. a4n12.1114

Hernández, J.; Aguirre, O.; Alanís, E.; Jiménez, J. y González, M. A. 2013. Efecto del manejo forestal en la diversidad y composición arbórea de un bosque templado del noroeste de México. Revista Chapingo serie Ciencias Forestales y del Ambiente, 19 (3), 189-199. http://www.redalyc.org/pdf/617/61750015003.p df

INIFAP (Instituto Nacional de Investigaciones forestales, Agrícolas y Pecuarias). 2012. Estadísticas Climáticas Normales del Estado de Jalisco. Centro de Investigación Regional Pacífico Centro. Libro Técnico No. 2. Jalisco. $132 \mathrm{p}$.

Juárez, S.M.; Domínguez C.P. y Návar CH.J. 2014. Análisis de la estructura silvícola en bosques de la Sierra de San Carlos, Tamaulipas, México. Foresta Veracruzana 16(1):25-34.

López, H. J.A.; Aguirre, C.O.A.; Alanís, R. E; Monárrez, G. J.C.; González, T.M. y Jiménez, P. J. (2017). Composición y diversidad de especies forestales en bosques templados de Puebla, México. Madera y Bosques, 23(1), 3951. doi:10.21829/myb.2017.2311518

Magurran, A.E.2004. Measuring biological diversity. Blackwell. Cambridge, USA. $256 \mathrm{p}$ http://silvicultoresdejalisco.org.mx/wpcontent/uploads/2017/05/Memoria-del-EstudioRegional-Forestal-1404.pdf
Martínez, S.M.; Pérez, S.G.; Gándara, V.G.A.; Hernández, L.A., González, M.C.J.; Armendáriz, O.R.; Chacón, S.M.J.; Moreno, G.A. y Meléndez, O.M.C. 2012. Estado actual del conocimiento de sitios permanentes de investigación silvícola (SPIS) en el estado de Chihuahua. SAGARPA-INIFAP. 125 p.https://brioagropecuario.com/index.php/2017/ 06/30/estado-actual-del-conocimiento-de-sitiospermanentes-de-investigacion-silvicola-spis-enel-estado-de-chihuahua/

Návar, C. J.J., y González, G. S. 2009. Diversidad, estructura y productividad de bosques templados de Durango, México. Polibotanica, 28, 71-87. Obtenido de http://www.scielo.org.mx/pdf/polib/n27/n27a5. pdf

Reyes, M. J. L.; Bretado, V. J. L.; Loera, G. M. H.; Simental, C.A.J.; Castillo, O. I.; Moreno, S. R.; Antuna, M. E. y Soto, M. A. 2016). Evaluación de existencias volumétricas conforme a la legislación forestal vigente en México. AGROFAZ, 16 (1) 77-83.

SEMARNAT (Secretaría de Medio Ambiente y Recursos Naturales). 2011. Anuario Estadístico de la Producción Forestal. 228 p.

URIBE, E. 2015. El cambio climático y sus efectos en la biodiversidad en América Latina. Santiago de Chile. Comisión Económica para América Latina y el Caribe (CEPAL). 84p. 